Brazilian Journal of Maize and Sorghum

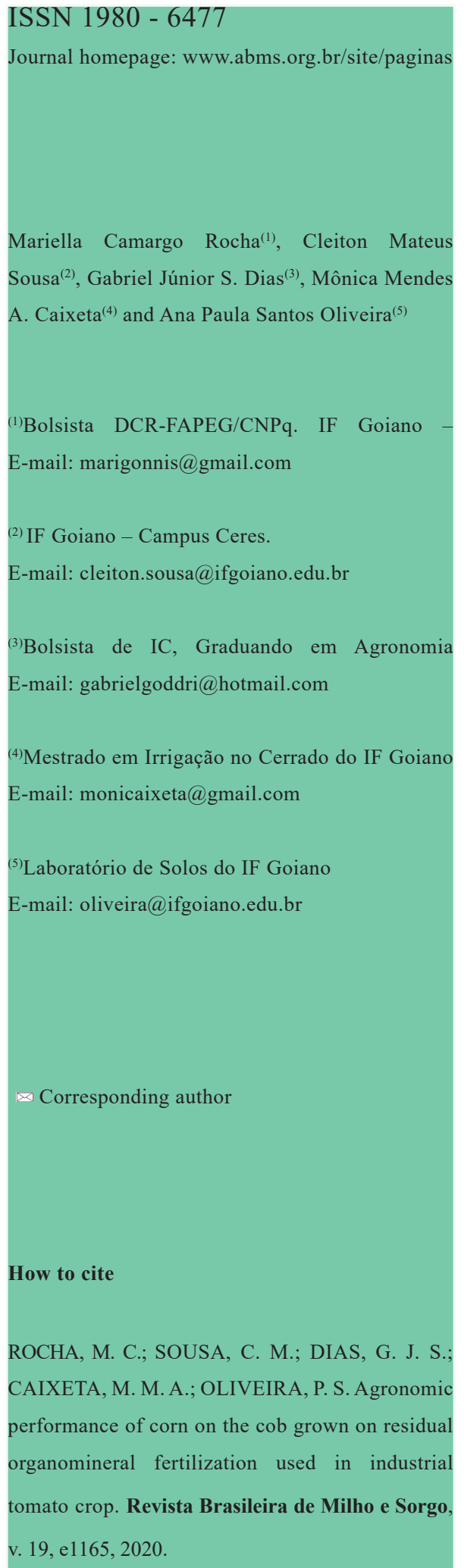

\section{AGRONOMIC PERFORMANCE OF CORN ON THE COB GROWN ON RESIDUAL ORGANOMINERAL FERTILIZATION USED IN INDUSTRIAL TOMATO CROP}

\begin{abstract}
The study evaluated the agronomic performance of corn on the cob grown on residual organomineral fertilization used in the industrial tomato crop. The randomized block design was used, with three replications and eight treatments as follows: control (without fertilizer application); mineral fertilizer; cattle manure; organomineral with cattle manure + MAP (monoammonium phosphate); chicken manure; organomineral with chicken manure + MAP; broiler litter; and organomineral with broiler litter + MAP. All of those treatments were applied to the tomato crop that preceded the corn on the cob. After the tomato harvest, maize was sown in the same tomato growing row. Growth variables of corn on the cob plants and ears were evaluated. The corn on the cob grown in areas with residues of chicken and cattle manure, used as fertilizers in the tomato crop preceding the maize crop, resulted in a number of commercial ears similar to when mineral fertilizer was used. The same similar results were obtained for ear quality and yield. The use of organic fertilizers in the industrial tomato crop presented high viability, which made possible to replace the use of mineral fertilizers in the subsequent green maize crop.
\end{abstract}

Keywords: Fertilizers, poultry and cattle manure, Zea mays L., Solanum lycopersicon L., crop succession.

\section{DESEMPENHO AGRONÔMICO DE MILHO-VERDE CULTIVADO SOBRE RESIDUAL DE ADUBAÇÃO ORGANOMINERAL NO TOMATEIRO INDUSTRIAL}

Resumo - Avaliou-se o desempenho agronômico de milho-verde cultivado sobre resíduos de adubação organomineral utilizada na cultura do tomateiro industrial. Utilizou-se o delineamento experimental de blocos ao acaso, com três repetições e oito tratamentos, sendo: testemunha (sem aplicação de fertilizante); fertilizante mineral; esterco bovino; organomineral à base de esterco bovino + MAP; esterco de galinha poedeira; organomineral à base de esterco de galinha poedeira + MAP; cama de frango de corte; e organomineral à base de cama de frango de corte + MAP; todas adubações realizadas para o cultivo do tomateiro, em antecipação ao cultivo do milho-verde. Após a colheita do tomate, realizou-se a semeadura do milho na linha de cultivo do tomateiro. Avaliou-se variáveis de crescimento das plantas e das espigas de milho-verde. O milhoverde cultivado em áreas com resíduos da adubação de esterco de galinha poedeira e esterco bovino, utilizados na cultura do tomateiro, antecedente à cultura do milho, proporcionou número de espigas comerciais semelhante ao fertilizante mineral, bem como rendimentos e qualidade das espigas. $\mathrm{O}$ uso de fertilizantes orgânicos utilizados na adubação do tomateiro industrial apresentou alta viabilidade e permitiu substituir a adubação mineral do cultivo subsequente do milho-verde.

Palavras-chave: Fertilizantes, dejetos de aves e bovinos, Zea mays L., Solanum lycopersicon L., sucessão de cultivos. 
The search for more sustainable production systems (Chieza et al., 2017), as well as for maintaining the system sustainability, demands techniques capable of keeping the soil fertility and minimizing the impacts to natural resources (Portugal et al., 2017). Among them, the crop succession has been long used, though, most of the time, with no information about fertilizer residues in the soil to reduce production costs (Souza Filho et al., 2016) and optimize the crop production.

Crop succession consists in the planned development of crops in order to avoid the successive planting of the same species or family, in the same area, over time (Madeira et al., 2015). It also enables staggered planting, reduction in the use of agrochemicals by breaking the pathogen life-cycle and diminishing its incidence, contribution to pest control, utilization of fertilizer residues, enhancement of root growth, and, consequently, increase of productivity indices (Souza \& Resende, 2014).

The state of Goiás is the main producer of industrial tomato in the country, with a total production of 111 tonnes ha-1 (Safra..., 2019). Taking into account the nutritional demands of the tomato plant and the crop management employed (Clemente \& Boiteux, 2012), the adoption of crop succession is considered appropriate, which allows the rational utilization of the agricultural inputs used.

Maize grain (Zea mays L.), due to its broad utilization, from in natura consumption up to a variety of industrial purposes, both for humans and animals, has a singular economic and social importance (Chieza et al., 2017). Although there is no recent information available in respect to the green maize production in Brazil, it is known that its production has been increasing both for in natura consumption and for the canned food industry. Currently, the "green maize business" is so promising that it has been encouraging producers of other crops to switch to green maize production. The increase of the product demand in the market has also been motivating producers, who employ family labor force, to increment the cottage industry, which resulted in increased income for that segment (Pereira Filho et al., 2011). Maize grain is the predominant crop used in succession to soybean (Freddi et al., 2017; Soares et al., 2018) and with potential to succeed other crops, such as the industrial tomato. However, evaluation has not yet been performed as to the residual effect of fertilizers applied to tomato crop to supply the demands of the green maize grown in succession.

Manure fertilization offers several benefits to the crops and the soil. However, most of the time, it does not meet the plant's demands due to its low concentration of some elements (Bissani et al., 2004). Thus, by enriching manure with minerals, it is possible to obtain the benefits with the use of manure and meet plant nutritional requirements (Bissani et al., 2004). Hence, the plants make better use of nutrients through the synchronized release throughout its development, with the addition of organic residues to the soil representing an important source of nutrients to 
the plants, especially nitrogen and phosphorus, which are made available after residues are decomposed by the soil microbiota (Kiehl, 1985).

Associations between organic and mineral fertilizers increase the nutrient uptake by the plants, which demonstrates that the use of organic fertilizers generates numerous longterm benefits, throughout the years, with future economic advantages (Possamai, 2016).

Organomineral fertilizers represent an alternative to revitalize the soil, since mineral fertilizers associated with organic fertilizers maximize the effects of the mineral nutrients that will be made available to the plants (Oliveira et al., 2005).

Organomineral fertilizers are obtained from the physical mixture or combination of mineral and organic fertilizers (Brasil, 2009), which favors sustainability and allows the fertilization to be efficiently performed, providing the nutrients required for plant growth, without compromising the environment and plant development. However, there are few reports on the influence of the use of organomineral fertilizer, produced with different sources of manure (broiler litter, chicken manure and cattle manure), on the production and quality of green maize grown in succession to tomato fertilized with the abovementioned sources.

Manure and organomineral fertilizers have specific dynamics of decomposition, mineralization and release of nutrients (Marschner, 1995). In view of that, it becomes necessary to study the effects of fertilization and residual effect of those fertilizers on the plants and soil.

Souza Filho et al. (2016) confirmed the viability of producing green maize in succession to melon crop, with no application of nitrogen and phosphorus. These two nutrients are important for green maize development (Scudeler et al., 2011; Silva et al., 2000) and are made available to the plants only by means of fertilization residues. Although the succession techniques are consolidated between some crops, there is no information about the cultivation of corn on the cob in succession to industrial tomato with the purpose of using the fertilizer residues in the soil.

Therefore, it is believed that the residual effect of organomineral fertilizers, produced with different types of manure and used in the industrial tomato crop, can provide good yields for the green maize grown in succession, when compared to other types of fertilization. The objective of this work was to assess the agronomic performance of corn on the cob grown on residual organomineral fertilization composed of different sources of animal manure and used in the industrial tomato crop.

\section{Material and Methods}

The experiment was carried out in the experimental area located in the municipality of Ceres, Goiás state, being the geographic coordinates $15^{\circ} 21^{\prime} 1.98^{\prime \prime} \mathrm{S}$ and $49^{\circ} 35^{\prime} 56.91^{\prime \prime}$ $\mathrm{W}$, with altitude of $566 \mathrm{~m}$, in the period from December 2016 to March 2017. The area had 
been used for cultivation of industrial tomato from May to October 2016.

According to Köppen's classification, the climate in the region is Aw type (hot semi-humid tropical), with well-defined season from May to September, and average annual precipitation, maximum and minimum temperature of 1575 $\mathrm{mm}, 30$ and $19^{\circ} \mathrm{C}$, respectively.

The soil in the experimental area was classified as Red Nitosol (Santos et al., 2018), with clay texture and slight elevations. In the 0 to $0.20 \mathrm{~m}$ layer, the soil presented 470.0, 100.0 and $430.0 \mathrm{~g} \mathrm{~kg}^{-1}$ of clay, sand and silt, respectively; $\mathrm{pH}($ water $)=5.2$; O.M. $=21 \mathrm{~g} \mathrm{dm}^{-3} ; \mathrm{P}=22.2$ $\mathrm{mg} \mathrm{dm}{ }^{-3} ; \mathrm{K}=0.40 \mathrm{cmolc} \mathrm{dm}^{-3} ; \mathrm{Ca}=2.6$ cmolc $\mathrm{dm}^{-3}$; and $\mathrm{Mg}=1.5$ cmolc $\mathrm{dm}^{-3}$. The analysis was carried out before the industrial tomato was planted, using the methodology provided by Claessen (1997).

Preparation of organomineral fertilizers consisted in grinding of chicken manure, cattle manure and broiler litter, incorporation of monoammonium phosphate (MAP) and granulation.

The treatments used in the experimental area were carried out in accordance with recommendation for industrial tomato crop (Clemente \& Boiteux, 2012), soil analysis and composition of the studied fertilizers, being as follows: 1 - mineral fertilizer ( $2 \mathrm{~g} \mathrm{plant}^{-1}$ of urea +17.5 g plant $^{-1}$ of single superphosphate $+3 \mathrm{~g}$ plant $^{-1}$ of KCl); 2 - cattle manure (40.9 g plant $^{-1}$ of manure +8.6 g plant $^{-1}$ of single superphosphate $+1.2 \mathrm{~g} \mathrm{plant}^{-1}$ of $\left.\mathrm{KCl}\right) ; 3$ - broiler litter $(28.1 \mathrm{~g}$ plant $^{-1}$ of broiler litter $+10.2 \mathrm{~g} \mathrm{plant}^{-1}$ of single superphosphate $+2.2 \mathrm{~g}$ plant $^{-1}$ of $\mathrm{KCl}$ ); 4 chicken manure (26.5 g plant $^{-1}$ of manure +10.4 g plant ${ }^{-1}$ of single superphosphate +2.1 g plant $^{-1}$ of $\mathrm{KCl}) ; 5$ - organomineral with cattle manure + MAP (16.7 g plant $^{-1}$ of organomineral + $2.2 \mathrm{~g}$ plant $^{-1}$ of single superphosphate +2.5 g plant $^{-1}$ of $\mathrm{KCl}) ; 6$ - organomineral with broiler litter + MAP (15.0 g plant ${ }^{-1}$ of organomineral $+2.1 \mathrm{~g}$ plant $^{-1}$ of single superphosphate +2.6 g plant $^{-1}$ of $\mathrm{KCl}$ ); 7 - organomineral with chicken manure + MAP (13.6 g plant ${ }^{-1}$ of organomineral + $3.6 \mathrm{~g}$ plant $^{-1}$ of single superphosphate +2.8 g plant $^{-1}$ of $\mathrm{KCl}$ ); and the control treatment with no fertilizer used.

The organic fertilizers presented the following ratio for $\mathrm{N}, \mathrm{P} \& \mathrm{~K}(\%)$ : cattle manure $(2.2,3.9,2.7)$; broiler litter $(3.2,4.7,1.9)$; chicken manure $(3.4,4.8,2.2)$; organomineral with cattle manure + MAP $(5.4,16.5,2)$; organomineral with broiler litter + MAP $(6,18.5,1.95)$; and organomineral with chicken manure + MAP (6.6, 18.4, 1.4).

Right after the industrial tomato crop was removed, direct seeding of AG 1051 corn on the cob was carried out in the same tomato planting furrows, with $1.00 \times 0.25 \mathrm{~m}$ spacing. The sprinkler irrigation system was used, with watering interval of three days, until reaching the soil field capacity.

Weeding was done 20 and 45 days after emergence in maize interrows. Spraying of insecticide/ acaricide (0.0-diethyl-0-(3,5,6trichloro-pyridyl)-phosphorothioate 1 L c.p. ha 
$\left.\mathrm{L}^{-1}\right)$ was done 43 days after sowing (DAS) for control of black cutworm.

Evaluation was performed 70 DAS for the following: total yield of unhusked ear $\left(\mathrm{Kg} \mathrm{ha}^{-1}\right)$; total yield of husked ear $\left(\mathrm{kg} \mathrm{ha}^{-1}\right)$; total number of ears (ears ha-1); average ear weight (g); number of commercial ears, which presented length of kernel set over $15 \mathrm{~cm}$, free of insect damages and diameter equivalent to or larger than $3.0 \mathrm{~cm}$ (Paiva Júnior et al., 2001); mass yield of commercial ears ( $\mathrm{kg}$ ); unhusked ear diameter ( $\mathrm{mm}$ ); husked ear diameter $(\mathrm{mm})$; husked ear length ( $\mathrm{mm})$; number of kernels per row (kernels/row ${ }^{-1}$ ); number of kernel rows (kernel rows ${ }^{-1}$ ); fresh mass of 100 grams of fresh grated maize (g); dry mass of 100 grams of grated maize $(\mathrm{g})$; plant height $(\mathrm{m})$; ear insertion height $(\mathrm{m})$; stem diameter $(\mathrm{mm})$; and total soluble solids ( ${ }^{\circ}$ Brix).

Data were submitted to analysis of variance through F-test and means were compared by Scott Knott test at 5\% probability. The software used for statistical analysis was Sisvar 4.0 (Ferreira, 2000).

\section{Results and Discussion}

The fertilizer residues used in the tomato crop influenced maize plant height, first ear insertion height, unhusked ear diameter, husked ear diameter, husked ear length, total yield of unhusked ears, and number of commercial ears.

Plants cultivated in the areas with residues of fertilization using chicken manure, organomineral with chicken manure + MAP, cattle manure, organomineral with cattle manure + MAP, control treatment, and mineral fertilizer presented height superior to the plants cultivated with broiler litter and organomineral with broiler litter + MAP (Figure 1).

Lemos et al. (2014) reported that broiler litter is rich in nitrogen, although being extremely necessary to use additives in order to reduce nitrogen losses to the atmosphere as ammonia. Therefore, some of the nitrogen available in the broiler litter and organomineral with broiler litter has probably been released during the tomato crop cycle, and adding that to the losses, there was no residual effect to enhance the height of maize plants grown in succession.

In regard to the first ear insertion height, chicken manure and control treatment presented the highest means when compared to the other treatments (Figure 1). Chicken manure is considered an important source of nutrients to the plants, with high nitrogen content (Boateng et al., 2006). The low carbon/nitrogen ratio of poultry manure (Santos et al., 2010) provides faster availability of most of the nutrients, especially nitrogen, to the plants (Figueroa et al., 2012). Raij et al. (1996) say that manure of poultry that received concentrate feed will certainly be richer than manure of cattle fed with grass of low nutritional value.

The residual effects of fertilization using mineral fertilizer, cattle manure, broiler litter, and organomineral with chicken manure + MAP, in the tomato crop, provided larger diameter of unhusked green maize ears in 


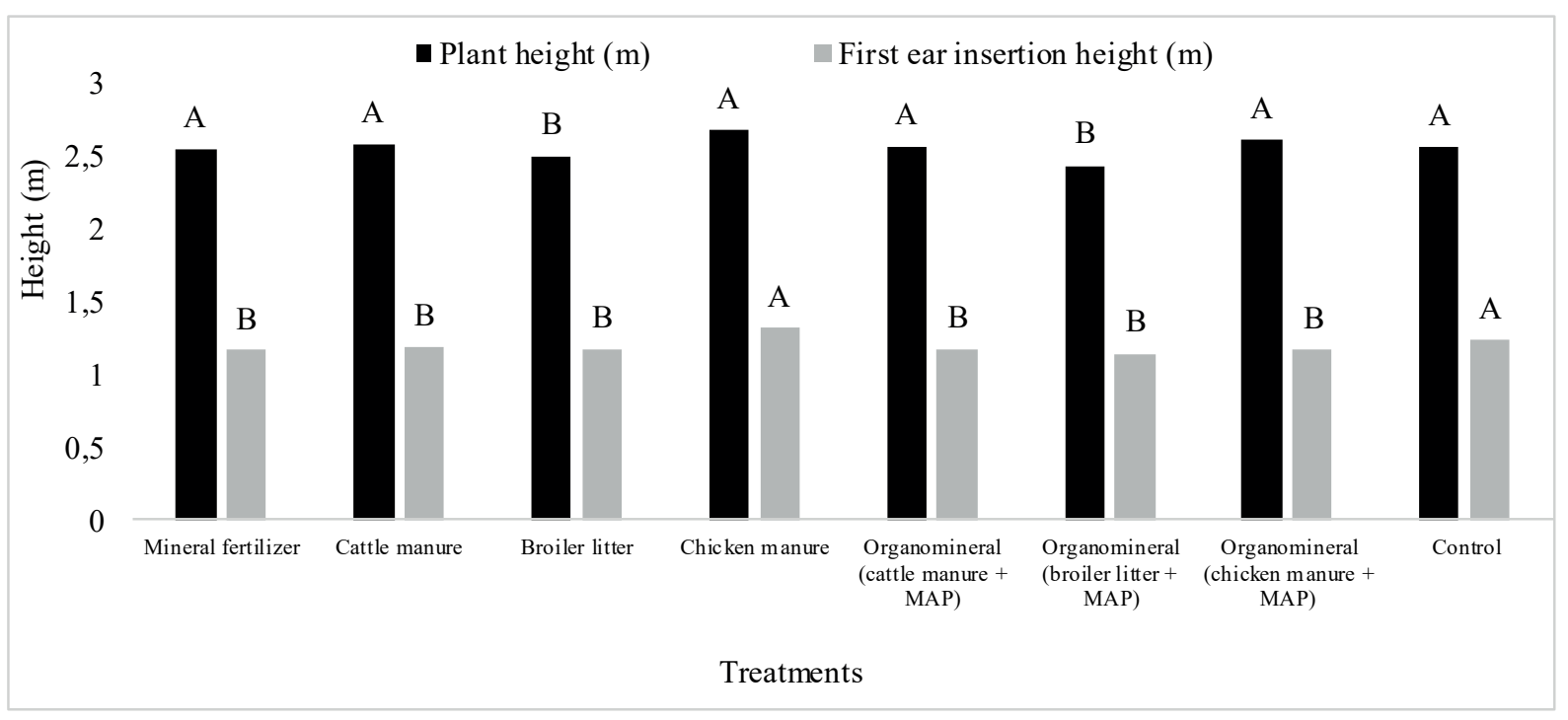

Figure 1. Plant height $(\mathrm{m})$ and first ear insertion height $(\mathrm{m})$ for green maize submitted to different sources of organomineral fertilization from December 2016 to February 2017. Federal Institute of Goiás - Ceres Campus, municipality of Ceres, Goiás state, 2017.

comparison with chicken manure, organomineral with broiler litter + MAP, control treatment, and organomineral with cattle manure + MAP $($ Table $1)$.

With regard to husked ear diameter, the best results were found in the areas with residual effects of fertilization with mineral fertilizer, cattle manure, broiler litter, organomineral combining chicken manure + MAP, and chicken manure (Table 1). Costa et al. (2015) found diameter of $47 \mathrm{~mm}$ for commercial ears of the AG 1051 hybrid when different doses de nitrogen were applied. Equivalent values were observed in this study for the plants grown in the area where mineral fertilizer was applied (Table 1).

In respect to husked ear length, mineral fertilizer, cattle manure, broiler litter, organomineral with chicken manure + MAP, and control treatment presented the highest means; while chicken manure, organomineral with broiler litter + MAP, and organomineral with cattle manure + MAP presented the lowest means (Table 1). Similar results were observed by Borges et al. (2012).

The highest total yield of unhusked ears was found in the treatments with residues of fertilization using chicken manure, cattle manure, mineral fertilizer, broiler litter, and organomineral with chicken manure + MAP, being superior to the yield observed in the treatments with residues of organomineral with broiler litter + MAP, control treatment, and organomineral with cattle manure + MAP (Table 1).

The amount of organomineral with broiler 


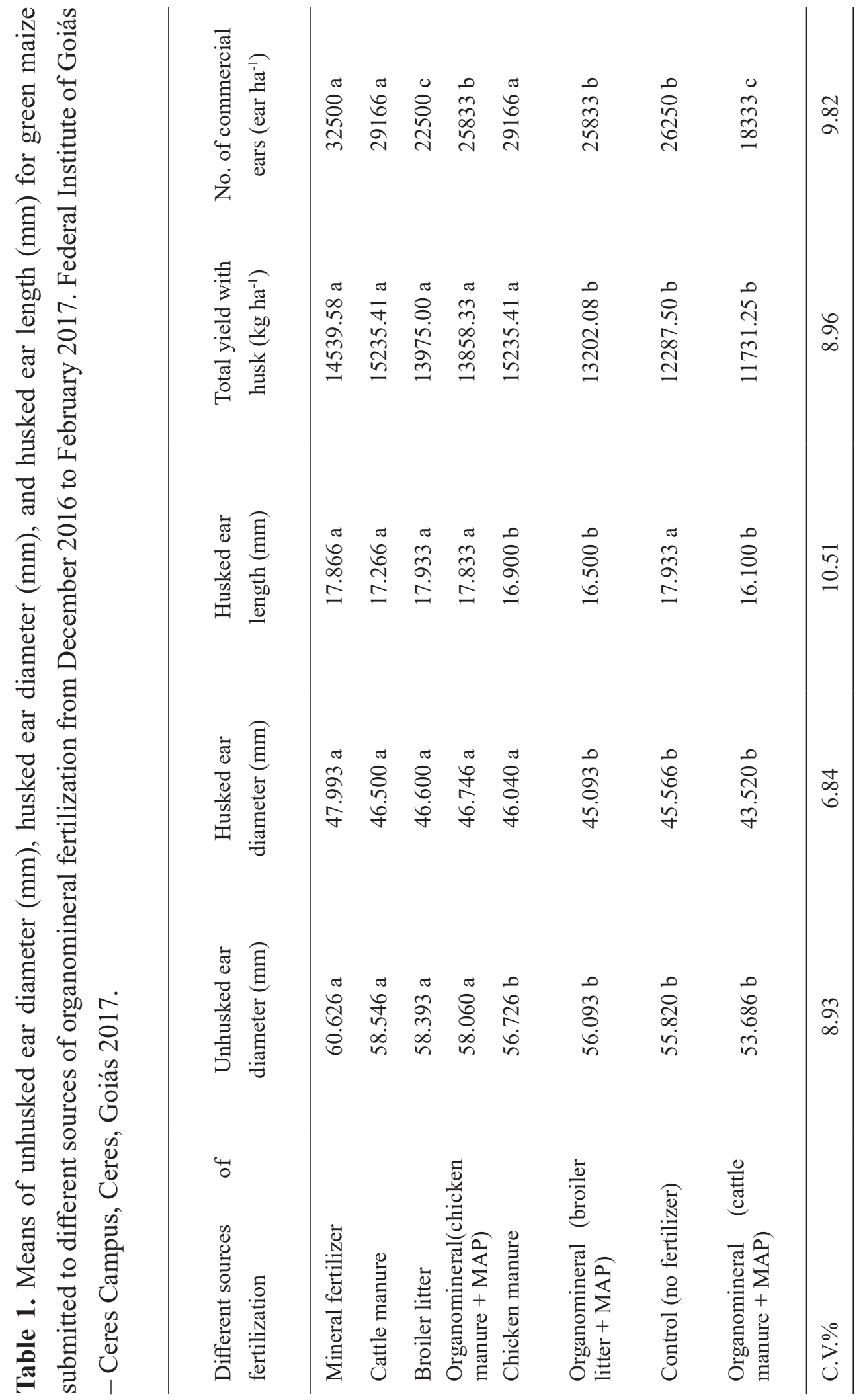


litter and organomineral with cattle manure applied to each plant was smaller than the quantity of chicken manure, cattle manure and broiler litter. That changes the fertilizer-soil interaction, the decomposition dynamics and, consequently, the influence on residual effects.

Organic fertilization changes the soil properties, such as moisture and temperature of the soil, which directly influence the process of decomposition and release of nutrients of the organic fertilizers (Kiehl, 1985). Probably, broiler litter and organomineral with broiler litter + MAP did not present the same decomposition dynamics in comparison with the other treatments, thus compromising the availability of nutrients necessary to obtain higher plants.

Peixoto Filho et al. (2013), when studying the yield of lettuce with application of broiler, cattle and sheep manure in successive crops, verified that the mineral fertilization provided good yields up to the second consecutive lettuce crop, while cattle and sheep manure provided high yields up to the third one. They also verified differences between the types of manure in the crop cycles, with the broiler manure being superior in the first cycle and the cattle and sheep manure being superior in the subsequent ones.

Sá et al. (2017) verified that the granulated organomineral phosphate fertilizer, prepared with broiler litter, provided greater accumulation of dry matter in maize plants in the first crop when compared to monoammonium phosphate.

The largest number of commercial ears was obtained in treatments with residues of fertilization using chicken manure, cattle manure and mineral fertilizer, while the lowest number was obtained with residues of broiler litter and organomineral combining cattle manure + MAP (Table 1).

Faster decomposition of broiler litter in relation to cattle manure occurs as a result of higher contents of $\mathrm{C}, \mathrm{N} \& \mathrm{~K}$, lower contents of lignin, cellulose and hemicellulose, and lower values of $\mathrm{C} / \mathrm{N}$ and lignin/ $\mathrm{N}$ ratios (Silva et al., 2014). Shah et al. (2013) highlighted that the quality of the residues determines their decomposition rates, so that, in general, organic residues with higher $\mathrm{C} \& \mathrm{~N}$ contents and lower $\mathrm{C} / \mathrm{N}$, lignin/ $\mathrm{N}$ and polyphenols/ $\mathrm{N}$ ratios decompose faster.

In that sense, the decomposition of organomineral fertilizers produced with broiler litter and organomineral with cattle manure + MAP occurred faster, when compared to the other treatments. Thus, in the ear formation period, there were not enough nutrients to meet the plant requirements and that, consequently, compromised the ear formation.

Albuquerque et al. (2008), when assessing the yield of unhusked AG 1051 hybrid ears, with application of mineral fertilizer, found the value of $13,144 \mathrm{~kg} \mathrm{ha}^{-1}$, which is lower than the value observed in this work in the treatments with chicken manure $(15235.41 \mathrm{~kg})$, cattle manure $(15235.41 \mathrm{~kg})$, mineral fertilizer (14539.58 $\mathrm{kg}$ ), broiler litter (13975.00 kg), organomineral with chicken manure + MAP (13858.33 kg), and organomineral with broiler litter + MAP (13202.08). The values observed in this study 
(Table 1) were higher than those observed by Costa et al. (2015) who, upon evaluation of the performance of different corn on the cob hybrids for consumption in natura, and fertilized with different doses of nitrogen, found yield of approximately $10.000 \mathrm{~kg} \mathrm{ha}^{-1}$ for the husked AG 1051 hybrid ears, when fertilized with $160 \mathrm{Kg}$ $\mathrm{ha}^{-1}$ of nitrogen. They highlight that the yields obtained are the result of using residues found in the planting area, thus demonstrating the efficiency of the use of different treatments.

The total yield of husked AG 1051 maize ears varied from 6,258 to $8,464 \mathrm{~kg} \mathrm{ha}^{-1}$. Greater numbers of ear per hectare were observed in the treatments with chicken manure, cattle manure and mineral fertilizer, which statistically differed from the other treatments (Table 1). The treatments with organomineral (cattle manure + MAP) and broiler litter presented the lowest means with 18,333 and 22,500 ears ha ${ }^{-1}$, respectively. Rocha et al. (2011), when assessing the effect of different planting densities of corn on the cob, found higher yield of 29.2 thousand ears ha ${ }^{-1}$ for husked AG 1051 hybrid ears, in the crop where mineral fertilizer was used, with a population of 60,000 plants per hectare.

Broiler litter and organomineral with broiler litter + MAP presented the worst results for plant height, which points to higher decomposition rate, as already indicated in the literature. At the end of the corn on the cob cycle, other fertilizers lost the residual effects and presented results similar to those found for broiler litter and organomineral with broiler litter + MAP. That demonstrates a variation in the residual effects of the fertilizers studied, and also that the use of plants in succession, with smaller cycle, allows a better utilization of the residual effects of organic fertilizers.

Residues of fertilization used in the tomato crop, which preceded the green maize crop, had no influence on the total yield of husked ear, average ear weight, ear mass yield, number of kernels per row, number of kernel rows, fresh mass of 100 grams of fresh grated maize, dry mass of 100 grams of grated maize, stem diameter, and total soluble solids ( $\left.{ }^{\circ} \mathrm{Brix}\right)$.

The organomineral fertilization used in the tomato crop provided sufficient amount of residues to allow the corn on the cob grown in succession to have ear quality and yield similar to the use of mineral fertilizer residues and similar to the values found in the literature.

There are other reports about the use of fertilization with different types of manure in maize crop that have been observed in the typical soil and climate conditions found in Brazil (Pereira Júnior et al., 2012), thus indicating that the application of manure from different sources may increase crop yield. However, there are few reports addressing the effect of organomineral fertilizer produced from different sources of manure on the yield and quality of corn on the cob.

\section{Conclusion}

The use of organic fertilizers in the tomato crop, which preceded the corn on the cob crop, 
proved to be a viable practice that reduces production costs and increases the producer's profitability, with its use being an alternative that can be applied to the production of maize for consumption as green ears.

\section{References}

ALBUQUERQUE, C. J. B.; VON PINHO, R. G.; SILVA, R. Produtividade de híbridos de milho verde experimentais e comerciais. Bioscience Journal, v. 24, n. 2, p. 69-76, 2008.

BISSANI, C. A.; GIANELLO, C.; TEDESCO, M. J.; CAMARGO, F. A. O. (Ed.). Fertilidade dos solos e manejo da adubação das culturas. Porto Alegre: Gênesis, 2004.

BOATENG, S. A.; ZICKERMANN, J.; KORNAHRENS, M. Poultry manure effect on growth and yield of maize. West Africa Journal of Applied Ecology, v. 9, n. 1, p. 1-11, 2006. DOI: 10.4314/wajae.v9i1.45682.

BORGES, I. D.; PEREIRA, R. S.; MARTISN, D. C.; CARVALHO, A. J.; CAMPOS, M. P.; MOTA, W. F.; CASTRO, G. F.; FRANÇA, J. A. Produção de milho verde em diferentes épocas de semeadura em Janaúba - M.G. In: CONGRESSO NACIONAL DE MILHO E SORGO, 29., 2012, Águas de Lindóia. Diversidade e inovações na era dos transgênicos: resumos expandidos. Campinas: Instituto Agronômico; Sete Lagoas: Associação Brasileira de Milho e Sorgo, 2012.
BRASIL. Ministério da Agricultura, Pecuária e Abastecimento. Instrução normativa n. 25 , de 23 de julho de 2009. Diário Oficial da União, Brasília, DF, n. 173, 28 jul. 2009. Seção 1. Disponível em: <https://www.gov.br/agricultura/ pt-br/assuntos/insumos-agropecuarios/insumosagricolas/fertilizantes/legislacao/in-25-de-23-72009-fertilizantes-organicos.pdf/view>. Acesso em: 21 fev. 2020.

CHIEZA, E. D.; GUERRA, J. G. M.; ARAÚJO, E. S.; ESPÍNDOLA, J. A.; FERNANDES, R. C. Produção e aspectos econômicos de milho consorciado com Crotalaria juncea L. em diferentes intervalos de semeadura, sob manejo orgânico. Revista Ceres, v. 64, n. 2, p. 189-196, 2017. DOI: $10.1590 / 0034-737 \times 201764020012$.

CLAESSEN, M. E. C. (Org.). Manual de métodos de análise de solo. 2. ed. rev. e atual. Rio de Janeiro: Embrapa-CNPS, 1997. 212 p. (Embrapa-CNPS. Documentos, 1).

CLEMENTE, F. M. V. T.; BOITEUX, L. S. (Ed.). Produção de tomate para processamento industrial. Brasília, DF: Embrapa, 2012. 344 p.

COSTA, F. R.; DAMASO, L. F.; MENDES, R. C.; MARQUES, D. D.; RODRIGUES, F. Desempenho de híbridos de milho para consumo in natura em diferentes doses de nitrogênio. Revista Científica, v. 43, n. 2, p. 109-116, 2015. DOI: 10.15361/1984-5529.2015v43n2p109-116. 
DICKMANN, L.; ANDREOTTI, M.; SOUZA, M. F. P.; NAKAO, A. H.; CATALANI, G. C Residual phosphate fertilization and Azospirillum brasilense in the common bean in succession to maize intercropped with Marandu grass. Revista Ciência Agronômica, v. 48, n. 3, p. 404-412, 2017.

ESPÍNDOLA, J. A. A.; GUERRA, J. G. M.; ALMEIDA, D. L.; TEIXEIRA, M. G.; URQUIAGA, S. Decomposição e liberação de nutrientes acumulados em leguminosas herbáceas perenes consorciadas com bananeira. Revista Brasileira de Ciência do Solo, v. 30, n. 2, p. 321-328, 2006. DOI: 10.1590/S010006832006000200012.

FERREIRA, D. F. Análises estatísticas por meio do Sisvar para Windows versão 4.0. In:

FIGUEROA, E. A.; ESCOSTEGUY, P. A. V.; WIETHÖLTER, S. Dosedeesterco deavepoedeira e suprimento de nitrogênio à cultura do trigo. Revista Brasileira de Engenharia Agrícola e Ambiental, v. 16, n. 7, p. 714-720, 2012. DOI: $10.1590 / \mathrm{S} 1415-43662012000700003$.

FREDDI, O. S.; TAVANTI, R. F. R.; SOARES, M. B.; AlMEIDA, F. T.; PERES, F. S. C. Physical-chemical quality of a latossol under direct seeding and soybean-corn succession in the cerrado-amazonian ecotone. Revista Caatinga, v. 30, n. 4, p. 991-1000, 2017. DOI: 10.1590/1983-21252017v30n420rc.
KIEHL, E. J. Fertilizantes orgânicos. São Paulo: Ceres, 1985. 482 p.

LEMOS, M. S.; MAIA, E.; FERREIA, E.; STACHIW, R. Uso da cama de frango como adubo na agricultura. Revista Brasileira de Ciências da Amazônia, v. 3, n. 1, p. 57-68, 2014.

MADEIRA, N. R.; LIMA, C. E. P.; MELO, R. A. C. Cultivo de hortalizas en sistemas de plantio directo (SPDH) para agricultura convencional y orgânica: estrategia para el control de arvenses y mejoramiento de propiedades físico-químicas del suelo. In: SEMINARIO INTERNACIONAL DE CULTIVOS HORTÍCOLAS DE ALTAS TEMPERATURAS PARA EL CARIBE COLOMBIANO, 2015, Cereté. Memoriasproceedings. Córdoba: Corpoica, 2015. p. 172187.

MARSCHNER, H. Functions of mineral nutrients: macronutrients. In: MARSCHNER, H. Mineral nutrition of higher plants. $2^{\text {nd }}$ ed. San Diego: Academic, 1995. p. 229-312.

OLIVEIRA, F. L.; RIBAS, R. G. T.; JUNQUEIRA, R. M.; PADOVAN, M. P.; GUERRA, J. G. M.; ALMEIDA, D. L.; RIBEIRO, R. L. D. Desempenho do consórcio entre repolho e rabanete com pré-cultivo de crotalária sob manejo orgânico. Horticultura Brasileira, v. 23, n. 2, p. 184-188, 2005. DOI: 10.1590/S010205362005000200004. 
PAIVA JÚNIOR, M. C.; PINHO, R. G.; PINHO, E. V. R.; RESENDE, S. G. Desempenho de cultivares para a produção de milho verde em diferentes épocas e densidades de semeadura em Lavras-MG. Ciência Agrotécnica, v. 25, n. 5, p. 1235-1247, 2001.

PEIXOTO FILHO, J. U.; FREIRE, M. B. G. S.; FREIRE, F. J.; MIRANDA, M. F. A.; PESSOA, L. G. M.; KAMIMURA, K. M. Produtividade de alface com doses de esterco de frango, bovino e ovino em cultivos sucessivos. Revista Brasileira de Engenharia Agrícola e Ambiental, v. 17, n. 4, p. 419-424, 2013. DOI: 10.1590/S141543662013000400010 .

PEREIRA FILHO, I. A.; CRUZ, J. C.; SILVA, A. R. da; COSTA, R. V. da; CRUZ, I. Milho verde. In: CRUZ J. C. Árvore do Conhecimento: milho. Brasília, DF: Embrapa, 2011. Disponível em: <https://www.agencia. cnptia.embrapa.br/gestor/milho/arvore/ CONT000fy779fnk02wx5ok0pvo4k3c1v9rbg. html>. Acesso em: 2 abr. 2020.

PEREIRA JÚNIOR, E. B.; HAFLE, O. M.; SÁ, J. M.; JANTALIA, C. P.; TEIXEIRA, OLIVEIRA, F. T.; OLIVEIRA, F. H. T.; GOMES, E. M. Produção e qualidade de milhoverde com diferentes fontes e doses de adubos orgânicos. Revista Verde de Agroecologia e Desenvolvimento Sustentável, v. 7, n. 2, p. 277 282, 2012.

PORTUGAL, J. R.; ARF, O.; PERES, A. R.;
GITTI, D. C.; GARCIA, N. F. S. Coberturas vegetais, doses de nitrogênio e inoculação com Azospirillum brasilense em milho no Cerrado. Revista Ciência Agronômica, v. 48, n. 4, p. 639-649, 2017.

POSSAMAI, L. Resposta da cultura do milho à adubação organomineral e adubação química. Cultura Agronômica, v. 25, n. 1, p. 71-78, 2016. DOI: 10.32929/2446-8355.2016v25n $1 \mathrm{p} 71-78$.

RAIJ, B. van; CANTARELLA, H.; QUAGGIO, J. A.; FURLANI, A. M. C. (Ed.). Recomendações de adubação e calagem para o Estado de São Paulo. 2. ed. Campinas:

Instituto Agronômico, 1996. 285 p.

ROCHA, D. R.; FORNASIER FILHO, D.; BARBOSA, J. C. Efeitos da densidade de plantas no rendimento comercial de espigas verdes de cultivares de milho. Horticultura Brasileira, v. 29, n. 3, p. 392-397, 2011. DOI: 10.1590/S0102-05362011000300023.

P. C.; POLIDORO, J. C.; BENITES, V. M.; ARAÚJO, A. P. Agronomic and $\mathrm{P}$ recovery efficiency of organomineral phosphate fertilizer from poultry litter in sandy and clayey soils. Pesquisa Agropecuária Brasileira, v. 52, n. 9, p. 786-793, 2017. DOI: 10.1590/S0100204X2017000900011. 
SAFRA de tomate industrial bate recorde de toneladas por hectare. Disponível em: $<$ http://www.sistemafaesc.com.br/Noticias/ Detalhe/13234>. Acesso em: 11 mar. 2019.

SANTOS, F. G. dos; ESCOSTEGUY, P. A. V.; RODRIGUES, L. B. Qualidade de compostos de esterco de ave poedeira submetido a dois tipos de tratamento de compostagem. Revista Brasileira de Engenharia Agrícola e Ambiental, v. 14, n. 10, p. 1101-1108, 2010. DOI: 10.1590/S141543662010001000012 .

SANTOS, H. G. dos; JACOMINE, P. K. T.; ANJOS, L. H. C. dos; OLIVEIRA, V. A. de; LUMBRERAS, J. F.; COELHO, M. R.; ALMEIDA, J. A. de; ARAÚJO FILHO, J. C. de; OLIVEIRA, J. B. de; CUNHA, T. J. F. Sistema Brasileiro de Classificação de Solos. 5. ed. rev. e ampl. Brasília, DF: Embrapa, 2018.

SCUDELER, F.; VENEGAS, F.; CORDEIRO, R. N. Avaliação técnica e econômica de fontes de nitrogênio em planta e cobertura na cultura do milho (Zea mays L.). Ensaios e Ciências, v. 15, n. 2, p. 67-75, 2011.

SHAH, G. M.; RASHID, M. I.; SHAH, G. A.; GROOT, J. C. J.; LANTINGA, E. A. Mineralization and herbage recovery of animal manure nitrogen after application to various soil types. Plant and Soil, v. 365, p. 69-79, 2013. DOI: $10.1007 / \mathrm{s} 11104-012-1347-8$.
SILVA, V. B.; SILVA, A. P.; DIAS, B. O.; ARAÚJO, J. L.; SANTOS, D.; FRANCO, R. P. Decomposição e liberação de N, P e K de esterco bovino e de cama de frango isolados ou misturados. Revista Brasileira de Ciência do Solo, v. 38, n. 5, p. 1537-1546, 2014. DOI: 10.1590/S0100-06832014000500019.

SILVA,C.E.;SILVAFILHO,A.V.;ALVARENGA, M. A. Efeito residual da adubação da batata sobre a produção de milho verde no cultivo sucessivo. Pesquisa Agropecuária Brasileira, v. 35, n. 11, p. 2151-2155, 2000. DOI: 10.1590/S0100204X2000001100005.

SOARES, G. F.; CRUZ, S. C. S.; DUARTE, T. C.; MACHADO, C. G.; SENA JÚNIOR, D. G. Gypsum and phosphorus in improving biometric and nutritional attributes of soybean/ second season corn succession. Revista Caatinga, v. 31 , n. 2 , p. $326-335$, 2018. DOI: 10.1590/1983-21252018v31n208rc.

SOUZA FILHO, A. L.; OLIVEIRA, F. H. T.; PRESTON, W.; SILVA, G. F.; CARVALHO, S. L. Nitrogen and phosphate fertilizer on green corn grown in succession to the melon crop.

Horticultura Brasileira, v. 34, n. 3, p. 392-397, 2016. DOI: 10.1590/S0102-05362016003014.

SOUZA, J. L.; RESENDE, P. Manual de horticultura orgânica. 3. ed. Viçosa, MG: Aprenda Fácil. 2014. 837 p. 